Article

\title{
Environmental Firms' Better Attitude towards Nature in the Context of Corporate Compliance
}

\author{
Rafael Robina Ramírez ${ }^{1}$ (1) and Pedro R. Palos-Sánchez ${ }^{2,3, *}$ \\ 1 Department of Business Management and Sociology, University of Extremadura, 10071 Caceres, Spain; \\ rrobina@unex.es \\ 2 Department of Business Administration and Marketing, University of Seville, 41018 Seville, Spain \\ 3 Department of Business Administration and Marketing, International University of La Rioja, \\ 26006 Logroño, Spain \\ * Correspondence: ppalos@us.es or pedro.palos@unir.net; Tel.: +34-941210211
}

Received: 21 August 2018; Accepted: 12 September 2018; Published: 17 September 2018

\begin{abstract}
The recent publishing of the Criminal Code Reform, known as the Corporate Governance Code and by which companies are prosecuted for the crimes they have committed, is contributing towards improving the management of companies involved in using natural resources. This study explores the disposition of environmental companies towards respect for nature in the context of the new Spanish Criminal Code 1/2015. Over 916 companies, including 104 environmental companies, have been asked about their knowledge of the code and the consequences it has for them through a survey. The paper explores the influence of regulatory compliance, coercive enforcement and cooperative actions on environmental companies to develop better attitudes towards nature. Partial Least Squares (PLS) Path Modelling was used to build an interaction model among variables. The results of the research reveal how environmental companies are more inclined to developing organizational standards (Cooperative Environmental Protocols) and to improving compliance with environmental law (coercive regulation). The model has a moderate predictive effect, explaining $54.1 \%$ of environmental companies' Better Attitude towards Nature. The findings may have important implications for environmental authorities when deterring environmental crimes.
\end{abstract}

Keywords: environmental companies; nature; coercive regulation; corporate compliance; organizational standards; surveillance; cooperative regulation; environmental crime; Spanish Criminal Code; PLS-SEM

\section{Introduction}

Environmental crimes have gradually increased despite the robust environmental policies implemented in the past two decades [1,2]. Administrative sanctions handed down by environmental agencies have lost their effectiveness [3]. The reasons behind this could be twofold. On the one hand, policies are rapidly updated to include many new items, making it difficult for companies to follow [4], and on the other, organizations and individuals have been driven to avoid complying with these regulations due to the lack of clarity in the environmental regulations, low economic sanctions and an absence of regular inspections and a sound legal policy to revert to in case of recidivism, etc. [5-7].

Since the industrial degradation, environmental entrepreneurs emerged quite rapidly as new companies in the environmental sector [8]. The sustainable research in the field of entrepreneurship has become crucial to deter threats to nature [9].

In this context, entrepreneurs have gradually sought to minimize the impact on the environment by seeking solutions to bring the economy closer to ecology [10]. This approach is based on developing 
processes, activities, actions and attitudes linked to the emerging green opportunities through organizational discoveries [11].

Likewise, extensive regulation has gradually increased to protect nature. The intention has been not only to make the environment a habitable place but also to increase the green awareness of sustainability within the company [12].

Regulatory compliance in environmental companies has been widely studied in the last decades [13-19]. Companies not only comply with the law for instrumental reasons (to avoid legal penalties) [20] but compliance has also guided companies' moral and civic duties [21].

Environmental corporate compliance has traditionally based itself on rules and the awareness of these rules to foster compliance with regulations. In other words, corporate regulations have focused on formal coercive structures to comply with the law and have had mixed results. Whereas the formal structure of corporate legal liability gives companies an incentive to reduce organizational misconduct [22], rules and regulations based on formal structures barely commit them to a type or degree of compliance [23]. Then, the only legal attempts to protect nature have not been consistent enough to address the environmental threat adequately [24].

More recently, Cooperative Environmental Protocols have played a relevant role in fostering environmental attitudes, and have revealed how rules influence employees' attitudes and ethical behavior [25].

In Spain, a new perspective from which to deter the environmental damages has emerged since regulatory compliance came about in 2015. The Criminal Code, which is based on judging criminal offences, was first introduced in Europe and years later in Spain with the aim of confronting organizations that fail to comply with environmental policies. For the first time in history, the Corporate Governance Code 1/2015 of 31 March 2015 [26], amending the previous Organic Law No. 10/1995 of November 23 [27], began prosecuting companies as opposed to individuals. The law provides for crimes committed by companies related to the planning of the territory and natural resources. In other words, this law comes into action when a company causes substantial damage to the quality of the air, soil or water, or to animals or plants.

In fact, several environmental companies have been sentenced since 2015. Recent court judgements passed by the Spanish Supreme Court Judgement [28,29]. Ever since the "Corporate Compliance" process was introduced, the outcome of these judgements has primarily been: economic penalties, claims for damages, loss of reputation and loss of competitiveness [30,31].

The aim of the Corporate Governance Code was not only to raise the legal pressure on illegal environmental companies but to encourage them to implement special surveillance measures to address the environmental crimes committed by companies properly. In other words, environmental companies must implement effective organizational surveillance and monitoring systems to avoid criminal sanctions being imposed and to better protect nature [32].

The lack of empirical studies in environmental companies after the recent approval of the Spanish Criminal Code has driven us to explore their influence on improving the attitudes towards nature. The environmental orientation of Spanish companies' and their willingness to develop stewardship strategies in companies through the cooperative business model was tested. This paper examines how environmental companies develop Better Attitudes towards Nature (BAN) either by following coercive procedures (Coercive Environmental Enforcement (COER)) or collaborative procedures (Cooperative Environmental Enforcement (COOP)). The aim is to guarantee the correct uses of natural resources by responding adequately to the environmental norms or developing organizational mechanisms in the context of the recent Spanish Corporate Governance Code [33].

To our knowledge, the relationship between how to develop BAN and the recent pressure exerted by the Spanish Corporate Governance Code (Corporate Compliance in Environmental matters (CCE)) has not been considered. In the circumstances, the contribution of the paper is twofold. First, to explore the willingness of environmental companies to develop organizational standards (cooperative environmental measures) and be more environmentally aware. Second, to ascertain 
the relevance of coercive regulations when it comes to developing environmental companies' better attitudes towards nature from the standpoint of the new Corporate Governance Code.

Four hundred and four environmental companies have already adhered to and fulfilled the requirements of the Spanish Criminal Code 1/2015. A statistical study was made using SmartPLS on the data collected [34]. The findings may have significant implications for environmental authorities when deterring environmental crimes. This research also adds to the current literature by providing new findings on how to incorporate the recent Corporate Governance Code into environmental decisions to enhance compliance with environmental law.

The paper is structured as follows. The first section analyses current corporate compliance in environmental companies. The second part links coercive and cooperative compliance with the law to the attitudes based on respect towards nature. The third section describes how SmartPLS has been used to study the variables and constructs from the data collected in 2017. The last part of the paper includes the results and conclusions of the research and the implications our findings may have for further research.

\section{Literature Review}

\subsection{Corporate Compliance in Environmental Issues}

The recent Spanish Criminal Code has expanded the provisions of Section 45 of the Spanish Constitution (1978) on the protection of the environment [35]. Section 347 bis of the first Criminal Code, approved in 1983 [36], clarified that he who violates the environmental provisions of the law mentioned above will be considered to have committed a crime and will, therefore, be subject to the appropriate administrative sanctions, as well as have an obligation to repair the damage caused. However, both the Criminal Codes of 1983 [36] and 1995 [27] still addressed crimes by accusing individuals instead of companies. It was not until 2010 when the code recognized the criminal responsibility of companies for the first time. Sections 31 and 33(7) of the Spanish Criminal Code 5/2010, of 22 June 2010 [36], explained the procedure to be followed to punish companies and the range of sanctions to be applied.

The 2015 version amended all earlier versions. The current wording of Section 173(1) explained in further detail what was to be understood by environmental crime and updated the applicable sanctions [26]. It stresses that, "Companies will be punished with imprisonment from six months to two years, a fine of ten to fourteen months and special disqualification for profession or trade for a period of one to two years which, in contravention of the laws or other provisions of general nature protective of the environment, directly or indirectly cause emissions, discharges, radiation, extractions or excavations, earthworks, noise, vibration, injections or deposits, in the atmosphere, soil, subsoil or terrestrial, underground or marine waters".

Even though individuals bear the end responsibility, liability is passed on to the company (vicarious liability). Therefore, the company's criminal liability is not direct, an individual must have committed a crime on its behalf [37]. This individual must have powers of representation, and de facto or de jure exercise the management, representation or government of the legal entity. Apart from companies' legal representatives, crimes can also be committed by employees in the exercise of corporate activities and for the account and benefit of legal entities. The legal entity can, therefore, not be attributed direct authorship of a crime, but at most, a form of participation in the crime committed by the individual [38].

The paper is focused on five hypotheses to measure the influence of the recent reformed Spanish Criminal Code on enhancing better attitudes towards nature. The hypotheses proposed for this study were:

1. $\mathrm{H}_{1}$-Corporate Compliance in Environmental matters (CCE) positively influences Better Attitude towards Nature (BAN).

2. $\mathrm{H}_{2}$ - Corporate Compliance in Environmental matters (CCE) positively influences Coercive Environmental Enforcement (COER). 
3. $\mathrm{H}_{3}$-Coercive Environmental Enforcement (COER) positively influences Better Attitude towards Nature (BAN).

4. $\mathrm{H}_{4}$-Corporate Compliance in Environmental matters (CCE) positively influences Cooperative Environmental Protocols (COOP).

5. $\mathrm{H}_{5}$-Cooperative Environmental Protocols (COOP) positively influences Better Attitude towards Nature (BAN).

Environmental regulations have gradually increased over the past decades to protect nature globally [39]. Despite the increased pressure of these regulations on companies, further improvement is still required to address environmental threats to nature adequately. Unfortunately, to date, these regulations have not been strong enough to reduce environmental crimes $[40,41]$.

In the context of the reformed Criminal Code, this study addresses how this law affects Spanish environmental companies. To be more specific, $\mathrm{H}_{1}$ intends to gain further insight into how the new the regulatory compliance influences the two critical aspects of environmental companies to improve their attitudes towards nature. These aspects are: (1) the balance between economy and ecology in environmental companies and (2) the awareness of the potential damages towards nature.

These key attributes also reflect the right stewardship perspective to deal with natural resources, which also raises the current debate between anthropocentrism and stewardship, i.e., the dialectics between those who emphasize the role of nature created explicitly for man's benefit, which has deteriorated the environment, and those who enhance the role of stewardship. Some questions arise in this respect: Is the new regulatory compliance oriented to the environment? Are the new legal systems that allow judges to prosecute companies—not only individuals—an effective weapon to better protect nature?

Hypotheses $\mathbf{1}\left(\mathbf{H}_{\mathbf{1}}\right)$. Corporate Compliance in Environmental matters positively influence Better Attitude towards Nature.

\subsection{Coercive Regulation in the Regulatory Compliance}

In the last decades, a far-reaching literature review has debated how environmental laws influence and are influenced by organizations [42]. The enforcement policies aimed at environmental companies have not only come from internal standards but also external governmental rules, including non-legal actions based on environmental activism [43] or competitive market dynamics [44]. These enforcement policies end up in measures of control imposed on environmental companies to respond to the external environmental demand.

The Corporate Compliance Regulation has channeled these external measures by pushing companies to comply with the environmental law. How the regulatory compliance influences the coercive norms within the environmental companies is a crucial factor. Willingness to observe the law is not relevant since regulatees do not develop the ability to comply with the law [45]. In other words, understanding how regulatees comply with the law is a prior condition to designing coercive environmental enforcement measures in companies.

Companies have proven to have two strong motivations when attempting to comply with the environmental law. First, the fear of violating the environmental law, and second, the sanctions imposed by public authorities if they do so.

For decades, the traditional regulatory enforcement has been built over the assumed proposal of the positive connection between the number of environmental norms and level of compliance. The increase of environmental rules has always been considered enough to raise environmental awareness and foster outcomes. Thus, in $\mathrm{H}_{2}$ the focus was not on the number of external rules that the company must adhere to, but on the real environmental control established over the employees and how this control is updated to respect nature more efficiently. Unfortunately, how those environmental rules are designed, updated and obeyed has typically played a secondary role. 
To bridge the gap, experts on regulations proposed six essential elements to motivate regulatees to comply with the environmental law $[46,47]$. First, the degree of motivation to comply with regulation and rules. The benefits of compliance should be higher than the risk of damage to the corporate reputation, the cost to put these rules into effect and the sanctions imposed otherwise. Second, the civic values contained in every regulation express a form of civic commitment [48]. Third, acceptance of the norms also depends on the reasonableness of the regulatory system [49] and the legitimacy of the authorities who enforce those rules [50]. Fourth, the social motivation to build their own reputation [51]. The willingness to comply with the law has a socializing effect on regulated environmental companies as they strive to earn social approval within the market. Social interaction has recently evolved due to technology, one of the key factors to link corporate compliance with coercive environmental enforcement. Fifth, the indispensable requisite of knowing the rules, namely of what a given regulation obliges one to do. Regulatees need to comprehend the regulations, which can be done by avoiding legal complexity and vagueness. Sixth, the capacity to comply with the law is also an essential factor. This capacity lays on several practical considerations, such as the cost of compliance, the financial capacity required from companies and the social pressure exerted.

The Criminal Code Reform has gone through all those considerations and yielded mixed results. First, the degree of motivation to comply with the law is addressed in the reform since the effect of the corporate law on companies provides companies two benefits: (1) control over corruption and its cost for the companies [52,53] and (2) reputational improvement by developing surveillance norms. Second, the civic values that regulate the companies' proper behavior are contained in the Introduction to the Spanish Corporate Code [26]. Third, the legitimacy to enforce legal compliance falls on the judiciary system, which is the most prestigious legal body in Spain. Fourth, the approach to social motivation in the current regulatory compliance system is crucial since reputational corporate actions are built around the level of legal compliance. Fifth, the current reformed law has failed to communicate its aims to the Spanish environmental companies since only 35\% of Spanish environmental companies are aware of the legal obligations of the Spanish Corporate Criminal Code. Only 20\% have incorporated the figure of a compliance officer, and 11\% have successfully developed and applied surveillance norms in the company. Sixth, compliance with the corporate law does not imply a high cost or complicated procedures. Judges do not impose rigid procedures to be implemented by environmental companies. Therefore, every company can use these indicators to suit their own procedures.

Coercive environmental norms are studied in the framework of a set of improved attitudes towards nature. First, it is fair to say that external environmental norms, such as governmental and legal, have provided a noticeable improvement in human-living conditions and nature [54]. From this perspective, coercive environmental enforcement has tried to achieve better compliance with the environmental law. This is one of the reasons behind the increase in environmental regulations and the expansion of the punishment systems almost at the same speed.

Environmental outcomes are critical in reaching a high standard of environmental compliance. However, it is common for companies to meet the minimal standards prescribed by the regulations. This means that the outcomes have not been as effective as expected [55,56]. As a result, environmental companies have not been able to build credibility appropriately in the eyes of stakeholders [57]. This lack of trustworthiness has led to the search for independent evaluations of these environmental reports.

As political and economic deterrence, new rules have been enforced to protect nature based on intimidation, threats, prosecution, apprehension, etc. These institutional pressures have been broadly studied recently [42,58]. However, the organizational system to prevent environmental crimes and achieve better attitudes towards nature goes beyond environmental regulations [59] and coercive measures [60].

Despite the adverse effects of the deterrence policy, the Spanish Criminal Code promotes coercive measures by prosecuting unlawful environmental companies, but it also allows companies to mitigate corporate sanctions, which exceed the regulatory perspective [61]. 
In this context, $\mathrm{H}_{3}$ analyses how the new legal deterrence programme introduced by the recent Criminal Code contributes towards improving companies' attitude towards nature.

Then, to be respectful to the environment, companies need to adapt their organizational management through the decision-making process. This was expressly highlighted in the reformed Spanish Code as the pivotal issue from which respectful decisions towards nature stem [62], represented by the voluntary disclosure of environmental standards to protect nature [63].

Hypotheses $2\left(\mathbf{H}_{\mathbf{2}} \mathbf{)}\right.$. Corporate Compliance in Environmental matters positively influences Coercive Environmental Enforcement.

Hypotheses $3\left(\mathbf{H}_{3}\right)$. Coercive Environmental Enforcement positively influences Better Attitude towards Nature.

\subsection{Cooperative Environmental Measures}

Developing organizational standards aims to protect nature, as explained in the above hypotheses. However, a second objective should also be noted. The Criminal Code offers the option to mitigate or avoid sanctions by developing surveillance measures to control the activities that might imply criminal behavior by companies.

From this legal scenario, such surveillance measures are not expressly required by law. In other words, these measures are not imposed coercively but collaboratively to avoid criminal sanctions on companies.

Impartial judges assess the organizational mechanisms developed by companies to respect nature based on the Spanish Corporate Governance Code in an attempt to guarantee the correct uses of natural resources. The recent Corporate Compliance programme has set out several managerial aspects, namely organizational standards, as part of this new culture [64]. By meeting this integral perspective, managers and employers are less likely to be prosecuted criminally.

Compliance officers (ECOs) design such organizational standards in their capacity as company management [65]. $\mathrm{H}_{4}$ reflects the efforts of compliance officers to design indicators and integrate respectful behavior towards the laws, organization regulations and rules through an appropriate decision-making model [66].

Officers can be established as an internal body or outsourced. There seems to be a consensus that compliance officers should be legal representatives or persons specifically appointed by the company and have knowledge on a wide array of subjects (criminal law, regulations and ethics). Their legitimacy is conferred by the organization to encourage employees to apply behavioral and ethical standards [67].

Corporate Compliance, therefore, guarantees the credibility of the standards by creating an ethical and organizational environment in companies $[68,69]$. By developing training programs and reporting performance management outcomes, officers enhance the employees' environmental commitment towards protecting nature [57], inspiring employees to support an ethical climate within the organizational procedures [70].

This new culture established by law not only prevents them from committing environmental crimes [71] but also from carrying out wrongful or uncertain environmental procedures [72].

For these procedure standards to be established [73], compliance officers must oversee their reliability [74] and ensure that the employees are made aware of them by inviting them to engage in training programs or spreading publications to explain them empirically, for instance.

Companies must also reassert the compliance procedure in place to detect possible environmental criminal conduct through auditing systems, and the appropriate disciplinary procedures must be attached, for use if not fulfilled.

The Explanatory Memorandum of the Spanish Corporate Governance Code 1/2015, of 31 March 2015 [26], underlines that companies should incorporate all possible mechanisms to prevent environmental crimes (Section 31 bis, Spanish Corporate Governance Code). 
These mechanisms provide a model of organization based on several items (see Figure 1): (1) Establishment of a management model that includes the appropriate surveillance and control measures to prevent crimes [75]. (2) Creation of a department to supervise the compliance when implementing the prevention model [76]. (3) Due diligence towards activities in which crimes are committed [77-79]. (4) To undertake training protocols or procedures to apply surveillance rules to either employers and employees [80-82]. (5) Allocation of financial resources to run the corporate preventive model $[83,84]$. (6) Report possible risks and non-compliances through whistleblowing channels [85]. (7) Establishment of a disciplinary system to prevent non-compliance through sanctions [86]. (8) Periodic verification of the preventive model and its timely update when relevant infractions are committed, and when organizational changes make them necessary $[87,88]$.

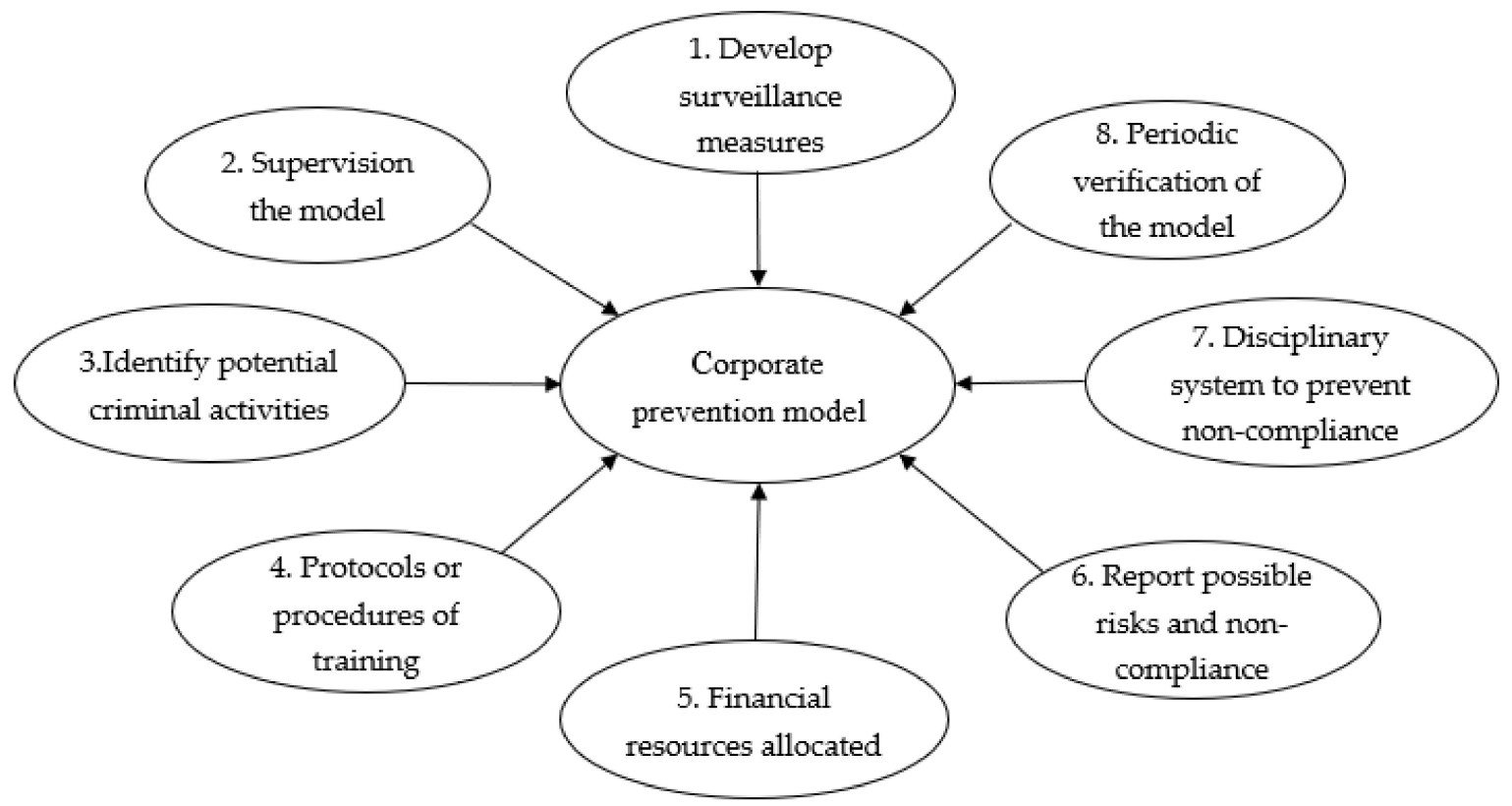

Figure 1. Organizational system to prevent environmental crime (Article 31 bis, Corporate Governance Code) [26].

The above hypotheses analyses the ability to comply with the law. $\mathrm{H}_{5}$ explores how cooperative measures designed by the compliance officers influence attitudes towards nature.

The reformed Corporate Law on Environmental matters has enhanced transparency and cooperation models with public authorities and regulatees [89-91].

The ethical approach nurtures these models and the civic values expressed in the Spanish Criminal Code. The values are the basis to raise awareness of cooperation processes among regulatees, to then fulfil the surveillance measures designed by the company. The aim is twofold: first, to follow the requirements announced with regulatory compliance to protect nature; second, to avoid information bias or any potential side effects of environmental policies.

$\mathrm{H}_{5}$ analyses how improved attitudes towards nature are related to the willingness to develop a cooperative model and apply organizational standards as well as strengthen moral behavior within the company. Companies must implement general cooperative guidelines based on moral actions towards nature by gaining the ethical skills to carry out their duties responsibly $[33,69]$. Companies must rely on organizational values and principles to develop this behavior appropriately, take the right decisions and allow internal or external agencies to monitor the environmental company [92].

This recent perspective turns resistance to behavioral changes in managers into flexibility and innovation in response to the challenges that the environment is currently facing [93,94]. 
This innovative response comes when companies focus more on finding environmentally ethical solutions [95] and discovering new opportunities to protect nature than in fulfilling rigid regulations [42]. Compliance officers must, therefore, take ethical solutions from the Corporate Compliance perspective. The Chief Ethics and Compliance Officers ensure that employers and employees behave legally and ethically.

Hypotheses $4\left(\mathbf{H}_{4}\right)$. Corporate Compliance in Environmental matters positively influences Cooperative Environmental Protocols.

Hypotheses $\mathbf{5}\left(\mathbf{H}_{5}\right)$. Cooperative Environmental Protocols positively influence Better Attitude towards Nature).

\section{Methodology}

\subsection{Measurement}

After a thorough literature review on the impact of the new Corporate Governance Code on environmental companies, the relationships, items and constructs presented in Figure 2 were proposed.

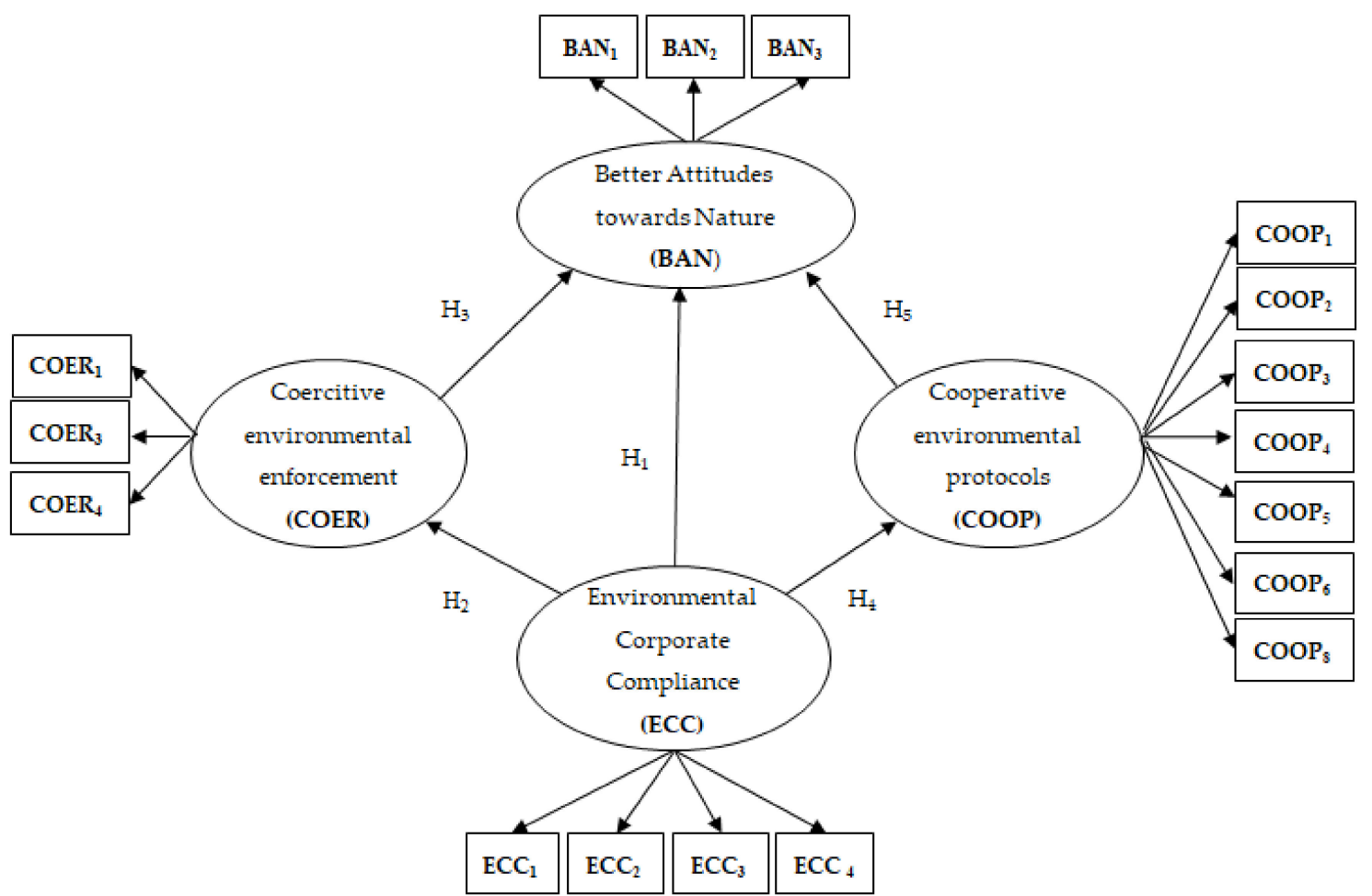

Figure 2. Conceptual scheme of the structural equation model utilized. Note: $\mathrm{H}_{1}$ : Hypotheses 1; $\mathrm{H}_{2}$ : Hypotheses 2; $\mathrm{H}_{3}$ : Hypotheses 3; $\mathrm{H}_{4}$ : Hypothesis 4; $\mathrm{H}_{5}$ : Hypothesis 5; BAN: Better Attitudes towards Nature; CEE: Corporate Compliance in Environmental matters; COER: Coercive Environmental Enforcement; COOP: Cooperative Environmental Protocols.

The items were designed considering the items of the questionnaire presented in Table 1 and were grouped around the proposed constructs.

The questions of the survey were measured through the five-point Likert scale used to indicate the degree of importance of the factors [96]. All factors or constructs were measured using a five-point Likert scale ranging from 1 ("strongly disagree") to 5 ("strongly agree"). Sampling was applied to the entire population. Of the 916 companies, 407 , representing $45 \%$ of the total responses, responded affirmatively to the survey. The survey was conducted over the phone, which entailed reading the questions and transcribing the answers. 
Table 1. Latent variables and the elaborated questionnaire.

\begin{tabular}{|c|c|}
\hline Latent Variables & Questions \\
\hline $\begin{array}{l}\text { BAN: } \\
\text { Better Attitudes towards Nature }\end{array}$ & $\begin{array}{l}\text { Is it important for your company to be aware of being a good } \\
\left.\text { steward of natural resources (BAN } \mathrm{B}_{1}\right) \text { ? } \\
\text { Is it important for your company to be oriented towards not } \\
\text { polluting the environment when investing in resources }\left(\mathrm{BAN}_{2}\right) \text { ? } \\
\text { Is it important for your company to have the attitude to respect } \\
\text { environment norms }\left(\mathrm{BAN}_{3}\right) \text { ? }\end{array}$ \\
\hline $\begin{array}{l}\text { CCE: } \\
\text { Corporate Compliance in Environmental Issues }\end{array}$ & $\begin{array}{l}\text { Is Corporate Compliance helping your company to respect } \\
\text { nature? }\left(\mathrm{CCE}_{1}\right) \\
\text { Is Corporate Compliance helping to prioritize Environmental } \\
\text { matters over economic ones? }\left(\mathrm{CCE}_{2}\right) \\
\text { Is Corporate Compliance helping you be more aware of possible } \\
\text { environmental damages }\left(\mathrm{CCE}_{3}\right) \text { ? } \\
\text { Is it important for you to have a Compliance Officer in charge of } \\
\text { developing organizational measures? }\left(\mathrm{CCE}_{4}\right)\end{array}$ \\
\hline $\begin{array}{l}\text { COER: } \\
\text { Coercive Environmental Enforcement }\end{array}$ & $\begin{array}{l}\text { Is it important for you to establish environmental control based } \\
\text { on organizational standards? }\left(\mathrm{COER}_{1}\right) \\
\text { Is it important for you to update the environmental control } \\
\text { standards in your company? }\left(\mathrm{COER}_{2}\right) \\
\text { Do you think that making the company responsible for } \\
\text { an environmental crime committed will contribute towards } \\
\text { respecting nature more efficiently? }\left(\mathrm{COER} \mathrm{R}_{3}\right) \\
\text { Is it important for you to avoid sanctions that may hinder the } \\
\text { reputation of the company? }\left(\mathrm{COER}_{4}\right)\end{array}$ \\
\hline $\begin{array}{l}\text { COOP: } \\
\text { Cooperative Environmental Enforcement }\end{array}$ & $\begin{array}{l}\text { Is it important to have a mechanism based on cooperative norms } \\
\text { to avoid legal sanctions? }\left(\mathrm{COOP}_{1}\right) \\
\text { Is it important to implement organizational standards, especially } \\
\text { in departments at a higher risk of committing crimes? }\left(\mathrm{COOP}_{2}\right) \\
\text { Is it important for you to develop a cooperative model between } \\
\text { public authorities and employees to respect nature? }\left(\mathrm{COOP}_{3}\right) \\
\text { Is it important for you to have guidelines to strengthen moral } \\
\text { behavior? (COOP }) \\
\text { Is it important for you to focus more on environmentally ethical } \\
\text { solutions and discover new opportunities to protect nature than } \\
\text { in the strict fulfilment of rigid regulations? }\left(\mathrm{COOP}_{5}\right) \\
\text { Is it important for you to set training protocols or procedures to } \\
\text { apply surveillance norms in your company? }\left(\mathrm{COOP}_{6}\right) \\
\text { Is it important for you to allocate financial resources to run the } \\
\text { corporate preventive model? }(\mathrm{COOP} 7) \\
\text { Is it important for you to include a disciplinary system to } \\
\text { prevent non-compliance through sanctions? (COOP })\end{array}$ \\
\hline
\end{tabular}

\subsection{Questionnaire}

An initial questionnaire was drafted based on the literature review. The questionnaire was previously validated through four qualitative interviews conducted during two focus groups organized in March 2018, involving important stakeholders belonging to both the private and public sectors.

The research team chose the waste management category among other options for two reasons: first, residue and waste have become the main threats to the environment [97-105]; second, the waste sector has more than 900 companies registered at the Ministry for Ecological Transition (Ministerio para la Transición Ecológica). It is undoubtedly a significant sample within Spanish environmental companies.

A total of 407 environmental companies participated in the study. The research team telephoned compliance officers and several heads of departments between January and March seeking responses to the questionnaire (see questions in Table 1). This sampling period was selected because directors are usually more willing to address research queries at the beginning of the year than any other time.

The questionnaire was validated through several procedures. The first was by conducting a pilot survey with a limited number of companies. This verified that the choice of items and constructs of the model were appropriate, and any that were ambiguous or could lead to errors were eliminated. 
As for the importance of these items, the reliability of the collected data was verified using a statistical software tool (IBM SPSS 24, IBM Corporation, Armonk, NY, USA) [106]. The values of the mean and the standard deviation were calculated accordingly. Subsequently, a t-test and one-dimensional variance analysis were carried out to verify the consistency in the opinions of the different groups of companies that participated in the survey. As a result of this process, items $\mathrm{COOP}_{7}$ and $\mathrm{COER}_{2}$ were eliminated from the original model, as can be seen in Figure 2. At the end of the process, Harman's single-factor test was used as a common method to measure publication bias [107]. The test did not detect any single factor that could explain most of the total variance, suggesting that bias is very unlikely.

The data obtained through the questionnaires were analyzed using structural equation modelling using variance (SEM). This statistical technique is applied when data are structured in a series of interrelated dependency relations between the latent variables of the theory and the indicators. They directly measure the observable variables [108]. The PLS technique (partial least squares) was also applied, specifically recommended for compound models or constructs $[108,109]$.

\subsection{Dates and Sample}

The structure and distribution of the population under study and in the sample is presented in Table 2, which shows the different business epigraphs ordered by categories and subcategories. Both are quantified by frequencies within the population and the sample.

Table 2. Waste management companies in Spain draw from the Ministry of the Ecological Transition.

\begin{tabular}{|c|c|c|c|}
\hline Category & Subcategory & Population & Sample \\
\hline \multirow{12}{*}{ Waste management } & Encapsulation of toxic compounds with mining matrix & 12 & 6 \\
\hline & Management of empty containers & 27 & 14 \\
\hline & Management of graphic arts waste & 20 & 10 \\
\hline & Management of pharmacy and hospital waste & 19 & 10 \\
\hline & Management of automotive workshops waste & 20 & 10 \\
\hline & Comprehensive management of industrial waste & 23 & 12 \\
\hline & Materials for waste incineration & 11 & 6 \\
\hline & Treatment of radioactive waste & 15 & 8 \\
\hline & Sludge and sludge treatments & 11 & 6 \\
\hline & Treatment and recycling of slurry & 15 & 8 \\
\hline & Treatment of paper recycling & 18 & 9 \\
\hline & Treatment of used oils and lubricants & 14 & 7 \\
\hline Subtotal & & 205 & 103 \\
\hline \multirow{9}{*}{$\begin{array}{l}\text { Collection and } \\
\text { transport of waste }\end{array}$} & Collection of fluorescent lamps & 11 & 4 \\
\hline & Collection of used batteries & 14 & 6 \\
\hline & Collection of urban solid waste & 21 & 8 \\
\hline & Collection and transport of sludge & 12 & 5 \\
\hline & Collection and transport of special waste & 13 & 5 \\
\hline & Collection and transportation of hospital waste & 12 & 5 \\
\hline & Aerosol collection vehicles & 15 & 6 \\
\hline & Pneumatic trash transport & 18 & 7 \\
\hline & Emergency environmental service & 14 & 6 \\
\hline Subtotal & & 130 & 52 \\
\hline \multirow{8}{*}{$\begin{array}{l}\text { Waste recovery } \\
\text { and recycling }\end{array}$} & Recovery of agricultural and livestock waste: composting & 18 & 7 \\
\hline & Appliance recovery & 13 & 5 \\
\hline & Recovery of toys and leisure equipment & 19 & 8 \\
\hline & Recovery and recycling of electronic waste & 14 & 6 \\
\hline & Recovery and recycling of wood & 15 & 6 \\
\hline & Recovery, treatment and recycling of the food sector & 19 & 8 \\
\hline & Recycling of materials & 18 & 7 \\
\hline & Recovery and recycling of packaging & 19 & 8 \\
\hline
\end{tabular}


Table 2. Cont.

\begin{tabular}{clcc}
\hline Category & \multicolumn{1}{c}{ Subcategory } & Population & Sample \\
\hline & Recovery and recycling of paper and cardboard & 18 & 7 \\
& Recovery and recycling of plastics and rubber & 19 & 8 \\
& Recovery and recycling of glass & 17 & 7 \\
& Recycling of ferrous and non-ferrous metals & 9 & 4 \\
& Recovery of hydrocarbons & 12 & 5 \\
& Recovery and recycling of demolition waste & 14 & 6 \\
& Recovery, recycling and textile valorisation & 22 & 9 \\
\hline Subtotal & & $\mathbf{2 4 6}$ & $\mathbf{9 8}$ \\
\hline Total & & $\mathbf{9 1 6}$ & $\mathbf{4 0 7}$ \\
\hline
\end{tabular}

\subsection{Regulatory Compliance in Different Types of Spanish Environmental Companies}

Table 3 shows that $77 \%$ of the companies are registered as "Limited liability" and $23 \%$ as "Public limited liability". The legal form is closely related to the size of the company in terms of employees. The majority of environmental companies (79\%) are "Micro" and "Small" companies, whereas 13\% are "Medium-sized" and 7\% are "Large" enterprises.

Table 3. Type of companies.

\begin{tabular}{lcc}
\hline \multicolumn{1}{c}{ Information } & $N=\mathbf{4 0 7}$ & Percentage (\%) \\
\hline Legal forms & & \\
\hline Limited liability company & 315 & 77 \\
Public limited liability company & 92 & 23 \\
Total & 407 & 100 \\
\hline Size of the company & & \\
\hline Microenterprises: less than 10 employees & 175 & 43 \\
Small enterprises: 10-49 employees & 148 & 36 \\
Medium-sized enterprises: 50-249 employees & 54 & 13 \\
Large enterprises: 250 or more employees. & 30 & 7 \\
Total & 407 & 100 \\
\hline
\end{tabular}

As Table 4 shows, data drawn from Spanish environmental companies reveal that $29 \%$ of the Spanish environmental companies are aware of regulatory compliance, and only $5 \%$ have incorporated an internal compliance officer's activity, whereas $17 \%$ resort to external compliance officers. This finding reveals another exciting breakthrough-namely, the 71 new compliance companies that have recently emerged in Spain.

From these environmental companies, $11 \%$ have successfully developed and applied surveillance norms in the company to avoid any potential unlawful acts committed by employees. 
Table 4. Regulatory compliance in Spanish environmental companies.

\begin{tabular}{lcc}
\hline \multicolumn{1}{c}{ Information } & $N=407$ & Percentage (\%) \\
\hline Any knowledge about the recent Spanish Corporate Compliance & & \\
\hline Yes & 119 & 29 \\
No & 288 & 71 \\
Total & 407 & 100 \\
\hline Compliance officer & & \\
\hline Internal compliance officer & 21 & 5 \\
External compliance officer & 71 & 17 \\
No & 315 & 77 \\
Total & 407 & 100 \\
\hline Surveillance norms & & \\
\hline Yes & 43 & 89 \\
No & 364 & 100 \\
Total & 407 & \\
\hline Disciplinary procedures & & 9 \\
\hline Yes & 35 & 91 \\
No & 372 & 100 \\
\hline
\end{tabular}

\section{Data Analysis}

\subsection{Analysis of the Measurement Model}

The individual reliability of the load $(\lambda)$ of each item was measured first. Typically, the minimum level for acceptance is established as part of the construct, which is $\lambda \geq 0.707$ [110].

Cronbach's alpha and its composite reliability (CR) were used to test the consistency of the constructs. This evaluation measures the consistency of a construct based on its indicators [111], that is, the rigor with which these elements measure the same latent variable.

Cronbach's alpha determines a consistency index for each construct and presents values between 0 and 1 . The lower limit for the construct reliability of acceptance is generally established between 0.6 and 0.7 [112]. As can be seen in Table 5, the highest validity will be in values close to 1 . All the variables indicated minimum validity. The most common measure to assess convergent validity in PLS-SEM is the average variance extracted (AVE). Using the same basis as that used with the individual indicators, an AVE value of $50 \%$ or higher means that, on average, a construct accounts for more than half of the variance of its own indicators $[113,114]$. Table 5 shows that all the constructs meet this criterion. Besides, another indicator known as rho_A is verified [115], where all constructs exceed the value 0.7.

Table 5. Cronbach alpha, rho_A, composite reliability, and average variance extracted (AVE).

\begin{tabular}{ccccc}
\hline & Cronbach's Alpha & rho_A & Composite Reliability & Average Variance Extracted (AVE) \\
\hline BAN & 0.831 & 0.835 & 0.898 & 0.747 \\
CCE & 0.890 & 0.896 & 0.924 & 0.754 \\
COER & 0.866 & 0.866 & 0.919 & 0.791 \\
COOP & 0.921 & 0.928 & 0.937 & 0.679 \\
\hline
\end{tabular}

The left part of Table 6 shows the correlations between the constructs. The square roots of the AVE are located on the diagonal of this table. A construct should share more variance with its measures or indicators than with other constructs in a given model [116]. Thus, the square root of the AVE (in bold) is greater than the correlation between that construct and the rest of the constructs in the model. There are grounds to affirm that constructs share more variance with their indicators than with other constructs of the model researched here [116] and have discriminant validity based on this first analysis. 
However, Henseler, Ringle and Sarstedt [117] developed simulation studies to demonstrate that a lack of discriminant validity is best detected by another technique: the heterotrait-monotrait (HTMT) ratio, developed by them. The results obtained are listed on the right side of Table 6, which enables verifying that all the HTMT ratios for each pair of factors are $<0.90$ [118].

Table 6. Measurement model: discriminant validity.

\begin{tabular}{lllllllll}
\hline & \multicolumn{3}{c}{ Fornell-Larcker Criterion } & \multicolumn{3}{c}{ Heterotrait-Monotrait Ratio (HTMT) } \\
\cline { 2 - 8 } & BAN & CCE & COER & COOP & BAN & CCE & COER & COOP \\
\hline BAN & 0.864 & & & & & & & \\
CCE & 0.640 & 0.868 & & & 0.735 & & & \\
COER & 0.511 & 0.528 & 0.889 & & 0.597 & 0.595 & & \\
COOP & 0.614 & 0.517 & 0.400 & 0.824 & 0.693 & 0.562 & 0.440 & \\
\hline
\end{tabular}

\subsection{Structural Model Analyses}

Table 7 shows the results related to contrasting the hypotheses formulated. These results show that the measurement model is satisfactory. The structural model was tested, and the statistical significance of the path coefficients were estimated based on a 5000-sample Bootstrapping test [119]. According to Chin [120], the crucial criterion for evaluating the structural model is the coefficient of determination $\left(R^{2}\right)$ of the endogenous latent variables. The $R^{2}$ must be above 0.2 to be considered moderate. Our endogenous constructs offer moderate values $\left(R^{2}\right.$ COER $\left.=0.279, R^{2} \mathrm{COOP}=0.268\right)$. The main endogenous construct yielded higher results $\left(R^{2} \mathrm{BAN}=0.541\right)$. Therefore, the evidence shows that this model is applicable in the context of Corporate Compliance and that it has a moderate to strong explanatory capacity.

The results presented in Table 7 show that all relationships are supported. All relationships are significant at $99.9 \%$ confidence levels, except for the relationship COER $\rightarrow$ BAN $(\beta=0.178$, $p$-value $=0.001)$ that is supported by a $99 \%$ confidence level. The relations with the greatest load are two: $\mathrm{CCE} \rightarrow \operatorname{COER}(\beta=0.528, T$-Statistic $=12.572)$ and CCE $\rightarrow$ COOP $(\beta=0.517, T$-Statistic $=11.072)$.

Regarding the measures of approximate adjustment of the model [121], the value is obtained from the residual root mean square [122], known as the SRMR. This measures the difference between the observed correlation matrix and the correlation matrix implied by the model. In our case, $S R M R=0.07$ is very close, but within the range, as it is said that a model has a goodness of fit when $S R M R<0.08$ [122].

The blindfolding procedure was used in respect to the predictive capacity of the model. To this end, part of the data for a given construct was omitted during the estimation of parameters and then what had been omitted was estimated using the estimation parameters [119]. The predictive relevance of the model was studied through the Stone-Geisser test $\left(Q^{2}\right)[123,124]$, which revealed that the model is predictive $\left(Q^{2}=0.377\right)$ since $Q^{2}>0$.

Table 7. Comparison of hypotheses.

\begin{tabular}{cccccc}
\hline Hypotheses & Effect & Path Coefficient $(\boldsymbol{\beta})$ & T-Statistic $(\beta / S T D E V)$ & $p$-Value & Significant \\
\hline $\mathrm{H}_{1}$ & $\mathrm{CCE} \rightarrow$ BAN & 0.362 & 8.910 & 0.000 & Yes \\
$\mathrm{H}_{2}$ & $\mathrm{CCE} \rightarrow \mathrm{COER}$ & 0.528 & 12.572 & 0.000 & Yes \\
$\mathrm{H}_{3}$ & $\mathrm{COER} \rightarrow \mathrm{BAN}$ & 0.178 & 3.396 & 0.001 & Yes $^{* *}$ \\
$\mathrm{H}_{4}$ & $\mathrm{CCE} \rightarrow \mathrm{COOP}$ & 0.517 & 11.072 & 0.000 \\
$\mathrm{H}_{5}$ & $\mathrm{COOP} \rightarrow$ BAN & 0.356 & 6.410 & 0.000 \\
\hline
\end{tabular}

Notes: For $N=5000$ subsamples, for $T$-distribution (499) Student's in single queue: ${ }^{*} p<0.05(T(0.05 ; 499)=1.64791345)$; ${ }^{* *} p<0.01(T(0.01 ; 499)=2.333843952) ; * * * 00.001(T(0.001 ; 499)=3.106644601)$. 


\section{Discussion}

\subsection{Theoretical Implications}

This research examined how Spanish environmental companies develop better attitudes towards nature by following coercive or collaborative procedures. The results obtained have a significant theoretical implication since they add new findings to the current literature on how to incorporate the recent Spanish Corporate Governance Code into environmental decisions and improve compliance with environmental legislation.

The findings of this research reveal that companies give special consideration to the new Corporate Compliance. This importance is manifested in the fact that the relations with the greatest statistical load are presented in $\mathrm{H}_{2}=\mathrm{CCE} \rightarrow \operatorname{COER}(\beta=0.528$, T-Statistic $=12.572)$. Therefore, at a theoretical level, this research shows that the implementation of Corporate Compliance in Spain has an important effect as a coercive measure. How regulatory compliance influences coercive norms in environmental companies is essential to understanding that compliance with the law is the prior condition for designing coercive environmental enforcement in companies. It is important to point out that whereas the formal structure of corporate legal liability gives companies an incentive to reduce organizational misconduct [22], rules and regulations based on formal structures barely commit them to a type or degree of compliance [23]. As $\mathrm{H}_{2}$ shows, environmental companies do not value the number of external rules to be complied with, but pass the control over to the employees instead. To increase the value of compliance, regulations must address key elements related to the benefits of compliance for the company [47]; address regulatory compliance's value [48]; and clarify the convenience [50] and the social motivation of the rules [51].

Likewise, $\mathrm{H}_{4}=\mathrm{CCE} \rightarrow \operatorname{COOP}(\beta=0.517, T$-Statistic $=11.072)$ is also highly significant. Environmental companies are particularly interested in evading the sanctions by developing surveillance measures to control the activities that may imply criminal behavior for companies. Findings show how environmental companies are interested in developing surveillance norms to protect nature through the regulatory compliance system. Similarly, cooperative Environmental Protocols have played a relevant role in fostering environmental attitudes stressing how rules influence employees' attitudes and ethical behavior [25]. However, these results must be taken cautiously due to the small number of companies aware of this regulation.

The same behavior occurs from the coercive point of view, and companies state that the new code makes it essential to establish an environmental control based on the rules of the organization, which update the control of environmental standards. Precisely, the responsibility of the company and its managers for an environmental crime contributes towards respecting nature more efficiently and prevents sanctions from damaging the reputation of the company.

The results, therefore, show that the new code fulfils its objective and that it not only increases legal pressure on illegal environmental companies but also encourages the implementation of special surveillance measures to address environmental crimes in companies. This fact leads us to agree with other research [10] which pointed out that companies should implement effective monitoring and organizational systems to avoid criminal sanctions and to better protect nature.

However, there is a relationship $\left(\mathrm{H}_{3}\right)$ that has the least statistical significance in the model. It could, therefore, be said that it is the relationship that is least present in the model. This relationship is between COER $\rightarrow$ BAN $(\beta=0.178, p$-value $=0.001)$, supported with a 99\% confidence level. Even though external environmental norms, such as governmental and legal norms, have provided a noticeable improvement in human-living conditions and nature, they are not enough to enhance environmental companies' better attitudes towards nature. This means that the environmental and economic outcomes have not been as effective as expected [55,56]. As a result, environmental companies have not been able to build credibility appropriately in the eyes of stakeholders [56]. Then, the only legal attempts to protect nature have not been consistent enough to address the environmental threat adequately [24]. $\mathrm{H}_{3}$ analyses how the new legal deterrence programme introduced by the recent Criminal Code 
contributes to improving companies' attitude towards nature. Despite the adverse effects of the deterrence policy, the Spanish Criminal Code promotes coercive measures by prosecuting unlawful environmental companies, but it also allows companies to mitigate corporate sanctions, which exceed the regulatory perspective [61].

The new regulatory compliance scenario has been understood as a step closer towards the prosecution of companies. For the first time in history, companies can be taken to court when employees commit unlawful actions. However, it is fair to say that the reformed law also allows companies to mitigate corporate sanctions. From this perspective, is quite reasonable to understand that severe punishment towards companies is not statistically significant.

\subsection{Practical Implications}

The findings obtained will have considerable implications for the Spanish and European environmental authorities and will help to further dissuade companies from committing environmental crimes.

From a practical point of view, the new code not only influences the improvement of the environmental performance of companies through coercive and cooperative measures, but it also has a direct effect. $\mathrm{H}_{1}$ shows this effect based on the findings of the relationship between CCE $\rightarrow$ BAN $(\beta=0.362, T$-Statistic $=8.910, p$-value $=0.000)$ with a high confidence level $(99.9 \%)$. This means that regulatory compliance positively influences the two key aspects of environmental companies, the balance between economy and ecology in environmental companies and the awareness of the potential damages to nature. Companies, therefore, understand that corporate compliance contributes towards respecting nature, prioritizing environmental matters over economic issues and being more aware of the potential environmental damage.

The fact that coercive measures have less influence than cooperative ones in companies' attitudes towards the environment has been predicted by some scholars [40,41]. This fact has both practical and theoretical implications. The recently published code will help environmental companies collaborate and become more aware to avoid sanctions that may adversely affect their reputations.

Another of the relations $\left(\mathrm{H}_{5}\right)$ discussed was that established between $\mathrm{COOP} \rightarrow \mathrm{BAN} . \mathrm{H}_{5}$ analyses how improved attitudes towards nature are related to the willingness to develop cooperative models to implement organizational standards and strengthen the moral behavior within the company. Then, findings show that compliance also has guided companies' moral and civic duties [21]. Companies must implement general cooperative guidelines based on moral actions towards nature by gaining the ethical skills to carry out their duties responsibly $[33,69]$.

Companies have not only considered it important to have a mechanism based on cooperative norms to avoid legal sanctions, but they also consider it a priority to develop a cooperative model between public authorities and employees to respect nature. These transparency and cooperation models have been widely introduced by the reformed corporate law [89-91].

The companies have considered that cooperative measures, such as implementing an organizational standard, especially in departments with the highest risk of committing crimes, are significantly influential $(\beta=0.356, p$-value $=0.000)$ with a confidence level of $99.9 \%$.

Finally, companies show a significant sensitivity towards the future of compliance with the new code through the organizational standards developed by the Compliance Officer. The companies surveyed considered it necessary to concentrate efforts on environmentally ethical and managerial solutions. This can be done by discovering new opportunities to protect nature instead of strictly complying with the regulations. This ethical relationship influences the future of the company as confirmed by the predictive value of the model $\left(Q^{2}=0.377\right)$.

Therefore, the establishment of training protocols or procedures to apply surveillance standards to employers and employees and allocate financial resources to execute the company's preventive model are vital to making the model more effective. 
Finally, the result obtained concerning the explanatory capacity of the model is moderately high $\left(R^{2} \mathrm{BAN}=0.541\right)$ and ensures that the new code will work as a disciplinary system to avoid sanctions.

\section{Conclusions}

This study had one primary aim: to study the effects of the publication of the new Code of Environmental Conduct for companies in Spain. Its objectives were measured from three points of view: the direct influence of the Spanish Criminal Code on improving environmental behavior towards nature, the influence that coercive measures exert over environmental companies and, finally, the cooperative standards within companies as surveillance measures to avoid sanctions.

The research concludes by stating that the three relationships have been tested and contrasted by the model and that the new code will contribute towards improving the attitudes of companies in the environmental sector. However, cooperative measures will have the most significant future and influence-not only because of the planning component they entail, but because of the impact they have on the results obtained.

Therefore, we recommend the authorities to relax the sanctioning capacity and promote organizational and ethical measures, because they focus on favoring and rewarding companies that establish protocols or training procedures to apply surveillance standards to employers and employees. Moreover, it is essential to allocate financial resources to execute the company's preventive model for the model to be effective. In this sense, part of the sanctions could be reversed if environmental training programmes are put into practice in these companies.

Another of the conclusions reached is the future importance of organizing a meeting and setting up avenues for collaboration between companies and public authorities. Having a mechanism based on cooperative rules to avoid legal sanctions could be a priority to improve the attitudes of companies in respect of nature. In this sense, this research recommends the creation of meeting spaces; for example, establishing public-private bodies, organizing conferences or meetings with companies or facilitating advertising campaigns that encourage compliance with environmental regulations.

The type of companies is also a strong point of the research due to its great impact on the environment. As you can see in Table 1, they are companies dedicated to the management, transport and recycling of waste. These categories have a notable influence on the sensitivity towards the environment since they are companies dedicated to improving the environment and reducing the impact of industrial activities. That is another reason why the research has focused on this type of environmental companies.

Concerning future research lines, the results should be compared with companies from other categories of business activity, to see if the results agree and the model is applicable.

An obvious limitation must be expressed. The recent publication of the code has no impact on this study. Temporary effects cannot be studied with a long temporal perspective, given its recen publication. A longitudinal study, as the second line of research, may be conducted in a few years' time. This would allow a reflection on the effect of the Spanish Corporate Governance Code on developing better attitudes towards nature with a broader perspective of environmental companies over time.

Author Contributions: R.R.R. carried out the research and wrote the theoretical part and methodology. P.R.P.-S. revised the methodology, analyzed the results and wrote the discussion and conclusion.

Funding: This research received no external funding.

Acknowledgments: The research behind the article was possible thanks to the Instituto Universitario de Investigación para el Desarrollo Territorial Sostenible (INTERRA) (Research Institute for Sustainable Territorial Development).

Conflicts of Interest: The authors declare no conflict of interest. 


\section{References}

1. El-Khoury, J. Environmental criminality: Field and legal study. Energy Procedia 2011, 6, 704-710. [CrossRef]

2. Stretesky, P.B.; Long, M.A.; McKie, R.E.; Aryee, F.A. Does oil and gas development increase crime within UK local authorities? Extr. Ind. Soc. 2018, 5, 356-365. [CrossRef]

3. Rooij, B.V.; McAllister, L.K. Environmental Law Enforcement Alliances in Middle-Income Countries; Peerenboom, R., Ginsburg, T., Eds.; Legal Studies Research Paper Series; Cambridge University Press: Chicago, IL, USA, 2014.

4. Handfield, R.B.; Melnyk, S.A.; Calantone, R.J.; Curkovic, S. Integrating environmental concerns into the design process: The gap between theory and practice. Trans. Eng. Manag. 2001, 48, 189-208. [CrossRef]

5. Faure, M.G.; Svatikova, K. Criminal or administrative law to protect the Environment? Evidence from Western Europe. J. Environ. Law 2012, 24, 253-286. [CrossRef]

6. Shimshack, J.P.; Ward, M.B. Enforcement and over-compliance. J. Environ. Econ. Manag. 2008, 55, 90-105. [CrossRef]

7. Nyborg, K.; Telle, K. Companies' compliance to environmental regulation: Is there really a paradox? Environ. Resour. Econ. 2006, 35, 1-18. [CrossRef]

8. Banerjee, A.V.; Duflo, E.; Munshi, K. The (mis) allocation of capital. J. Eur. Econ. Assoc. 2003, 1, $484-494$. [CrossRef]

9. Koe, W.L.; Majid, I.A. Socio-cultural factors and intention towards sustainable entrepreneurship. Eurasian J. Bus. Econ. 2014, 7, 145-156.

10. Hockerts, K.; Wüstenhagen, R. Greening Goliaths versus emerging Davids-Theorizing about the role of incumbents and new entrants in sustainable entrepreneurship. J. Bus. Ventur. 2010, 25, 481-492. [CrossRef]

11. Schaltegger, S.; Synnestvedt, T. The link between 'green' and economic success: Environmental management as the crucial trigger between environmental and economic performance. J. Environ. Manag. 2002, 65, 339-346.

12. Gliedt, T.; Parker, P. Green community entrepreneurship: Creative destruction in the social economy. Int. J. Soc. Econ. 2007, 34, 538-553. [CrossRef]

13. Dechant, K.; Altman, B. Environmental leadership: From compliance to competitive advantage. Acad. Manag. Perspect. 1994, 8, 7-20. [CrossRef]

14. Biondi, V.; Frey, M.; Iraldo, F. Environmental management systems and SMEs. Greener Manag. Int. 2000, 29, 55-69. [CrossRef]

15. Kagan, R.A.; Gunningham, N.; Thornton, D. Explaining corporate environmental performance: How does regulation matter? Law Soc. Rev. 2003, 37, 51-90. [CrossRef]

16. Gunningham, N.; Kagan, R.A.; Thornton, D. Social license and environmental protection: Why businesses go beyond compliance. Law Soc. Inq. 2004, 29, 307-341. [CrossRef]

17. Liu, N.; Tang, S.Y.; Lo, C.W.H.; Zhan, X. Stakeholder demands and corporate environmental coping strategies in China. J. Environ. Manag. 2016, 165, 140-149. [CrossRef] [PubMed]

18. Amoiralis, E.I.; Andriosopoulos, K. Challenges for a compliance officer in the liberalised EU energy market: A case study on the Greek gas transmission system operator. Energy Policy 2017, 110, 117-125. [CrossRef]

19. Naidoo, M.; Gasparatos, A. Corporate Environmental Sustainability in the retail sector: Drivers, strategies and performance measurement. J. Clean. Prod. 2018, 203, 125-142. [CrossRef]

20. Hawkins, K.; Hutter, B. The Response of Business to Social Regulation in England and Wales. Law Policy 1993, 15, 199-218. [CrossRef]

21. Wright, M.S. Factors Motivating Proactive Health and Safety Management; Contract Research Report prepared by Entec U.K. Ltd. for the Health and Safety Executive London; Her Majesty's Stationery Office: Norwich, UK, 1998.

22. Krawiec, K.D. Cosmetic compliance and the failure of negotiated governance. Wash. ULQ 2003, 81, 487. [CrossRef]

23. Edelman, L.B. Legal ambiguity and symbolic structures: Organizational mediation of civil rights law. Am. J. Sociol. 1992, 97, 1531-1576. [CrossRef]

24. García-Sanchez, I.; Cuadrado-Ballesteros, B.; Frias-Aceituno, J. Impact of the institutional macro context on the voluntary disclosure of CSR information. Long Range Plan. 2016, 49, 15-35. [CrossRef] 
25. Winter, S.C.; May, P.J. Motivation for compliance with environmental regulations. J. Policy Anal. Manag. 2001, 20, 675-698. [CrossRef]

26. New Penal Code Amendment, Organic Law 1/2015. Available online: https://www.boe.es/buscar/pdf/ 2015/BOE-A-2015-3439-consolidado.pdf (accesses on 15 June 2018).

27. Spanish Criminal Code 10/1995. Código Penal. Available online: http://www.wipo.int/wipolex/en/text. jsp?file_id=269097 (accessed on 6 June 2018).

28. Spanish Supreme Court. Judgement 251/2016 of 31 March 2016, Appeal 1837/2015.

29. Spanish Supreme Court. Judgement 516/2016 of 13 June 2016, Appeal 1765/2015.

30. Kuhlen, L. Cuestiones fundamentales de Compliance y Derecho penal. In Compliance y Teoría del Derecho Penal; Marcial Pons: Madrid, Spain, 2013; pp. 51-76.

31. Bock, D. Compliance y deberes de vigilancia en la empresa. In Compliance y teoría del Derecho Penal; Marcial Pons: Madrid, Spain, 2013; pp. 107-122.

32. Partnoy, F. Infectious Greed: How Deceit and Risk Corrupted the Financial Markets; Profile Books: London, UK, 2003.

33. Namiri, K.; Stojanovic, N. A model-driven approach for internal controls compliance in business processes. In Proceedings of the Workshop on Semantic Business Process and Product Lifecycle Management (SBPM), Innsbruck, Austria, 7 June 2007.

34. Ringle, C.M.; Wende, S.; Becker, J.M. “SmartPLS 3" Boenningstedt: SmartPLS GmbH. 2015. Available online: http:/ / www.smartpls.com (accessed on 14 May 2018).

35. Spanish Constitution. Congreso de los Diputados. 1978. Available online: http://www.congreso.es/ portal/page/portal/Congreso/Congreso/Hist_Normas/Norm/const_espa_texto_ingles_0.pdf (accessed on 10 June 2018).

36. Spanish Criminal Code 8/1983, 25 June. Available online: https://www.boe.es/buscar/doc.php?id=BOEA-1983-17890 (accessed on 21 July 2018).

37. Spanish Criminal Code 5/2010, of 22 June. Sections 31 and 33(7). Available online: https: / /www.boe.es / buscar / doc.php?id=BOE-A-2010-9953 (accessed on 21 July 2018).

38. Quintero Olivares, G. La Reforma Penal de 2010: Análisis y Comentarios; Aranzadi: Madrid, Spain, 2010 ; p. 58. Available online: http:/ / pcbjuridico.es/docs/libros/reforma-penal-2010.pdf (accessed on 20 July 2018).

39. Boldova Pasamar, M.Á. La introducción de la responsabilidad penal de las personas jurídicas en la legislación española. Rev. Estudios Penales Criminológicos 2013, 92173, 219-263.

40. Sethi, S.P.; Martell, T.F.; Demir, M. Enhancing the role and effectiveness of corporate social responsibility (CSR) reports: The missing element of content verification and integrity assurance. J. Bus. Ethics 2017, 144, 59-82. [CrossRef]

41. Francis, J.R.; Khurana, I.K.; Martin, X.; Pereira, R. The relative importance of firm incentives versus country factors in the demand for assurance services by private entities. Contemp. Account. Res. 2011, 28, 487-516. [CrossRef]

42. Sutton, J.R.; Dobbin, F.; Meyer, J.W.; Scott, W.R. The legalization of the workplace. Am. J. Sociol. 1994, 99, 944-971. [CrossRef]

43. Reid, E.M.; Toffel, M.W. Responding to public and private politics: Corporate disclosure of climate change strategies. Strat. Manag. J. 2009, 30, 1157-1178. [CrossRef]

44. Chatterji, A.K.; Toffel, M.W. How companies respond to being rated. Strat. Manag. J. 2010, 31, 917-945.

45. Ramirez, R.R.; Palos-Sanchez, P.R. Willingness to Comply with Corporate Law: An Interdisciplinary Teaching Method in Higher Education. Sustainability 2018, 10, 1-21. [CrossRef]

46. Burby, R.J.; Paterson, R.G. Improving compliance with state environmental regulations. J. Policy Anal. Manag. 1993, 12, 753-772. [CrossRef]

47. Tyler, T.R. Why People Obey the Law; Princeton University Press: New Haven, CT, USA.

48. Scholz, J.T.; Pinney, N. Duty, fear, and tax compliance: The heuristic basis of behavior. Am. J. Polit. Sci. 1995, 39, 490-512. [CrossRef]

49. Levi, M. Of Rule and Revenue; University of California: Berkeley, CA, USA, 1988; Volume 13.

50. Grasmick, H.G.; Bursik, R.J., Jr. Conscience, significant others, and rational choice: Extending the deterrence model. Law Soc. Rev. 1990, 24, 837-861. [CrossRef]

51. Mauro, P. Corruption and growth. Q. J. Econ. 1995, 110, 681-712. [CrossRef] 
52. Argandoña, A. The United Nations convention against corruption and its impact on international companies. J. Bus. Ethics 2007, 74, 481. [CrossRef]

53. Gunningham, N.; Sinclair, D. Partnerships, management systems and the search for innovative regulation in the vehicle body shop industry. Bus. Strateg. Environ. 2002, 11, 236-253. [CrossRef]

54. Bardach, E.; Kagan, R.A. Conclusion: Responsibility and accountability. In Social Regulation: Strategies for Reform; Bardach, E., Kagan, R.A., Eds.; Institute for Contemporary Studies: San Francisco, CA, USA, 1982; pp. 343-360.

55. Hodge, K.; Subramaniam, N.; Stewart, J. Assurance of sustainability reports: Impact on report users' confidence and perceptions of information credibility. Aust. Account. Rev. 2009, 19, 178-194. [CrossRef]

56. Gray, R. A re-evaluation of social, environmental and sustainability accounting: An exploration of an emerging trans-disciplinary field? Sustain. Account. Manag. Policy J. 2010, 1, 11-32. [CrossRef]

57. Darnall, N.; Henriques, I.; Sadorsky, P. Adopting proactive environmental strategy: The influence of stakeholders and firm size. J. Manag. Stud. 2010, 47, 1072-1094. [CrossRef]

58. Majumdar, S.K.; Marcus, A.A. Rules versus discretion: The productivity consequences of flexible regulation. Acad. Manag. J. 2001, 44, 170-179.

59. Markel, D. 'Slack' in the administrative state and its implications for governance: The issue of accountability. Oregon Law Rev. 2005, 84, 1-22.

60. Triantis, K.; Otis, P. Dominance-based measurement of productive and environmental performance for manufacturing. Eur. J. Oper. Res. 2004, 154, 447-464. [CrossRef]

61. Dhaliwal, D.S.; Radhakrishnan, S.; Tsang, A.; Yang, Y.G. Nonfinancial disclosure and analyst forecast accuracy: International evidence on corporate social responsibility disclosure. Account. Rev. 2012, 87, 723-759. [CrossRef]

62. Clarkson, P.M.; Li, Y.; Richardson, G.D.; Vasvari, F.P. Revisiting the relation between environmental performance and environmental disclosure: An empirical analysis. Account. Organ. Soc. 2008, 33, 303-327. [CrossRef]

63. Krages, B.P. How responsible are corporate officers for environmental compliance? Met. Finish. 1997, 95, 40-45. [CrossRef]

64. Wong, R.; Millington, A. Corporate social disclosures: A user perspective on assurance. Account. Audit. Account. J. 2014, 27, 863-8887. [CrossRef]

65. Gnazzo, P.J. The chief Ethics and Compliance Officer: A test of endurance. Bus. Soc. Rev. 2011, 116, 533-553. [CrossRef]

66. Tyler, T.; Dienhart, J.; Thomas, T. The ethical commitment to compliance: Building value-based cultures. Calif. Manag. Rev. 2008, 50, 31-51. [CrossRef]

67. Simnett, R.; Vanstraelen, A.; Chua, W.F. Assurance on sustainability reports: An international comparison. Account. Rev. 2009, 84, 937-967. [CrossRef]

68. Deegan, C.; Cooper, B.J.; Shelly, M. An investigation of TBL report assurance statements: UK and European evidence. Manag. Audit. J. 2006, 21, 329-371. [CrossRef]

69. Greenberg, M.D. Perspectives of Chief Ethics and Compliance Officers on the Detection and Prevention of Corporate Misdeeds: What the Policy Community Should Know; RAND Corporation: Santa Monica, CA, USA, 2009.

70. De Porres Ortiz de Urbina, E. Responsabilidad Penal de las Personas Jurídicas; El Derecho: Madrid, Spain, 2015.

71. Moroney, R.; Windsor, C.; Aw, Y.T. Evidence of assurance enhancing the quality of voluntary environmental disclosures: An empirical analysis. Account. Financ. 2012, 52, 903-939. [CrossRef]

72. Bampton, R.; Cowton, C. Taking stock of accounting ethics scholarship: A review of the journal literature. J. Bus. Ethics 2013, 114, 549-563. [CrossRef]

73. Calderón, R.; Ferrero, I.; Redin, D.M. Ethical codes and corporate responsibility of the most admired companies of the world: Toward a third generation ethics? Bus. Polit. 2012, 14, 1-24. [CrossRef]

74. Lynch, M. The culture of control: Crime and social order in contemporary society. PoLAR Political Leg. Anthropol. Rev. 2002, 25, 109-112. [CrossRef]

75. Ingrisano, J.A.; Mathews, S.A. Practical Guide to Avoiding Failure to Supervise Liability. Prev. Law Rep. 1995, $14,12$.

76. Huff, K.B. The role of corporate compliance programs in determining corporate criminal liability: A suggested approach. Columbia Law Rev. 1996, 96, 1252-1298. [CrossRef] 
77. Gruner, R.S. Towards an Organizational Jurisprudence: Transforming Corporate Criminal Law Through Federal Sentencing Reform. Ariz. Law Rev. 1994, 36, 407.

78. Blum, J.A.; Levi, M.; Naylor, R.T.; Williams, P. Financial havens, banking secrecy and money-laundering. Crim. Justice Matters 1999, 36, 22-23. [CrossRef]

79. Warhurst, A. Future roles of business in society: The expanding boundaries of corporate responsibility and a compelling case for partnership. Futures 2005, 37, 151-168. [CrossRef]

80. Sadiq, S.; Governatori, G.; Namiri, K. Modeling control objectives for business process compliance. In Proceedings of the International Conference on Business Process Management, Brisbane, Australia, 24-28 September 2007; Springer: Berlin/Heidelberg, Germany, 2007; pp. 149-164.

81. Govindarajulu, N.; Daily, B.F. Motivating employees for environmental improvement. Ind. Manag. Data Syst. 2004, 104, 364-372. [CrossRef]

82. Vandenbergh, M.P. Beyond elegance: A testable typology of social norms in corporate environmental compliance. Stan. Envtl. LJ 2003, 22, 55.

83. Gabel, H.L.; Sinclair-Desgagné, B. Managerial incentives and environmental compliance. J. Environ. Econ. Manag. 1993, 24, 229-240. [CrossRef]

84. Amicelle, A. Towards a 'new' political anatomy of financial surveillance. Secur. Dialogue 2011, 42, 161-178. [CrossRef]

85. MacNeil, I.; Li, X. "Comply or Explain": Market discipline and non-compliance with the Combined Code. Corp. Gov. Int. Rev. 2006, 14, 486-496. [CrossRef]

86. De Maglie, C. Models of corporate criminal liability in comparative law. Wash. Univ. Glob. Stud. Law Rev. 2005, 4, 547.

87. Campbell, D.R.; Campbell, M.; Adams, G.W. Adding significant value with internal controls. CPA J. 2006, 76, 20.

88. Nussbaum, M. Educação e Justiça Social; Edições Pedago: Rmada, Spain, 2014.

89. Verrax, F. Engineering ethics and post-normal science: A French perspective. Futures 2017, 91, 76-79. [CrossRef]

90. Slater, J.; Angel, I.T. The impact and implications of environmentally linked strategies on competitive advantage: A study of Malaysian companies. J. Bus. Res. 2000, 47, 75-89. [CrossRef]

91. Andreen, W. Motivating enforcement: Institutional culture and the CleanWater. Act. Pace Environ. Law Rev. 2007, 24, 67-98.

92. Rest, J.R. Moral Development: Advances in Research and Theory; Praeger: New York, NY, USA, 1986.

93. Eberlein, B.; Matten, D. Business responses to climate change regulation in Canada and Germany: Lessons for MNCs from emerging economies. J. Bus. Ethics 2009, 86, 241-255. [CrossRef]

94. Jackson Susan, E.; Jane, E.D. Discerning threats and opportunities. Adm. Sci. Q. 1988, 33, 370-387. [CrossRef]

95. Russo, M.V.; Paul, A.F. A resource-based perspective on corporate environmental performance and profitability. Acad. Manag. J. 1997, 40, 534-559.

96. Morimoto, R.; Ash, J.; Hope, C. Corporate social responsibility audit: From theory to practice. J. Bus. Ethics 2005, 62, 315-325. [CrossRef]

97. Porter, M.; Van der Linde, C. Green and competitive: Ending the stalemate. The Dynamics of the eco-efficient economy: Environmental regulation and competitive advantage. Harv. Bus. Rev. 1995, 33, 119-134.

98. Allen, I.E.; Seaman, C.A. Likert scales and data analyses. Qual. Prog. 2007, 40, 64.

99. Michaelson, C. Compliance and the illusion of ethical progress. J. Bus. Ethics 2006, 66, 241-251. [CrossRef]

100. Pimentel, D.; Moran, M.A.; Fast, S.; Weber, G.; Bukantis, R.; Balliett, L.; Young, M. Biomass energy from crop and forest residues. Science 1981, 212, 1110-1115. [CrossRef] [PubMed]

101. Groenewegen, P.; Vergragt, P. Environmental mattersas threats and opportunities for technological innovation. Technol. Anal. Strat. Manag. 1991, 3, 43-55. [CrossRef]

102. Sabbas, T.; Polettini, A.; Pomi, R.; Astrup, T.; Hjelmar, O.; Mostbauer, P.; Heuss-Assbichler, S. Management of municipal solid waste incineration residues. Waste Manag. 2003, 23, 61-88. [CrossRef]

103. Embrandiri, A.; Singh, R.P.; Ibrahim, H.M.; Ramli, A.A. Land application of biomass residue generated from palm oil processing: Its potential benefits and threats. Environment 2012, 32, 111-117. [CrossRef]

104. Singh, P.; Sulaiman, O.; Hashim, R.; Peng, L.C.; Singh, R.P. Using biomass residues from oil palm industry as a raw material for pulp and paper industry: Potential benefits and threat to the environment. Environ. Dev. Sustain. 2013, 15, 367-383. [CrossRef] 
105. Gupta, A.; Verma, J.P. Sustainable bio-ethanol production from agro-residues: A review. Renew. Sustain. Energy Rev. 2015, 41, 550-567. [CrossRef]

106. IBM Corporation. IBM SPSS Statistics for Windows, version 24.0; IBM Corporation: Armonk, NY, USA, 2013.

107. Guo, Z.; Xiao, L.; Van Toorn, C.; Lai, Y.; Seo, C. Promoting online learners' continuance intention: An integrated flow framework. Inf. Manag. 2016, 53, 279-295. [CrossRef]

108. Sarstedt, M.; Hair, J.F.; Ringle, C.M.; Thiele, K.O.; Gudergan, S.P. Estimation issues with PLS and CBSEM: Where the bias lies! J. Bus. Res. 2016, 69, 3998-4010. [CrossRef]

109. Rigdon, E.E.; Sarstedt, M.; Ringle, C.M. On Comparing Results from CB-SEM and PLS-SEM: Five Perspectives and Five Recommendations. Mark. ZFP 2017, 39, 4-16. [CrossRef]

110. Carmines, E.G.; Zeller, R. Reliability and Validity Assessment; Sage Publications: Newbury Park, CA, USA, 1979.

111. Götz, O.; Liehr-Gobbers, K.; Krafft, M. Evaluation of structural equation models using the Partial Least Squares (PLS) a roach. In Handbook of Partial Least Squares; En, W.W.V., Esposito, V., Eds.; Springer: Berlin, Germany, 2010; pp. 691-711.

112. Hair, J.; Black, W.; Babin, B.; Anderson, R.; Tatham, R. Multivariate Data Analysis, 5th ed.; Prentice Hall: Upper Saddle River, NJ, USA, 2005.

113. Fornell, C.; Larcker, D.F. Structural equation models with unobservable variables and measurement erroralgebra and statistics. J. Mark. Res. 1981, 18, 382-388. [CrossRef]

114. Hair, J.; Hult, G.T.; Ringle, C.; Sarstedt, M. A Primer on Partial Least Squares Structural Equation Modeling (PLS-SEM); SAGE Publications, Inc.: Saunders Oaks, CA, USA, 2014.

115. Dijkstra, T.K.; Henseler, J. Consistent and asymptotically normal PLS estimators for linear structural equations. Comput. Stat. Data Anal. 2015, 81, 10-23. [CrossRef]

116. Henseler, J.; Ringle, C.M.; Sinkovics, R.R. The use of partial least squares path modelling in international marketing. Adv. Int. Mark. 2009, 20, 277-320.

117. Henseler, J.; Ringle, C.M.; Sarstedt, M. A new criterion for assessing discriminant validity in variance-based structural equation modelling. J. Acad. Mark. Sci. 2015, 43, 115-135. [CrossRef]

118. Gold, A.H.; Malhotra, A.; Segars, A.H. Knowledge management: An organisational capabilities perspective. J. Manag. Inf. Syst. 2001, 18, 185-214. [CrossRef]

119. Tenenhaus, M.; Vinzi, V.; Chatelin, Y.; Lauro, C. PLS path modelling. Comput. Stat. Data Anal. 2005, 48, 159-205. [CrossRef]

120. Chin, W. The partial least squares approach to structural equation modelling. Mod. Methods Bus. Res. 1998, 295, 295-336.

121. Henseler, J.; Hubona, G.; Ray, P.A. Using PLS path modelling in new technology research: Updated guidelines. Ind. Manag. Data Syst. 2016, 116, 2-20. [CrossRef]

122. Hu, L.T.; Bentler, P.M. Fit indices in covariance structure modelling: Sensitivity to underparameterized model misspecification. Psychol. Methods 1998, 3, 424. [CrossRef]

123. Stone, M. Cross-validatory choice and assessment of statistical predictions. J. R. Stat. Soc. 1974, 111-147.

124. Geisser, S. A Predictive Approach to the Random Effects Model. Biometrika 1974, 61, 101-107. [CrossRef]

(C) 2018 by the authors. Licensee MDPI, Basel, Switzerland. This article is an open access article distributed under the terms and conditions of the Creative Commons Attribution (CC BY) license (http://creativecommons.org/licenses/by/4.0/). 